Grażyna NOWICKA

IEiB UKSW Warszawa

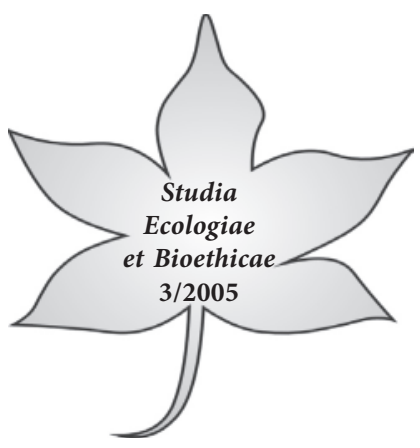

\title{
Otyłość - ważny problem zdrowotny
}

Otyłość, czyli nadmierna (tzn. przekraczająca ustalone normy) akumulacja tkanki tłuszczowej, uznawana jest aktualnie za jeden z kluczowych problemów zdrowotnych społeczeństw krajów rozwiniętych i rozwijających się. Światowa Organizacja Zdrowia mówi o epidemii otyłości i wskazuje, iż staje się ona niezmiernie ważnym problemem zdrowia publicznego $\mathrm{w}$ tych krajach, gdyż występuje już u ponad 30\% ludności (1-5). Otyłość jest stanem na bazie którego rozwijają się choroby układu krążenia, nadciśnienie tętnicze, cukrzyca typu II, wiele chorób nowotworowych, w tym rak trzonu macicy, jajników i sutka u kobiet, rak okrężnicy i odbytnicy a także prostaty u mężczyzn. Ponadto sprzyja ona powstawaniu kamicy pęcherzyka żółciowego oraz zwyrodnień układu kostno-stawowego. W Stanach Zjednoczonych ocenia się, że leczenie chorób bezpośrednio związanych z otyłością pochłania rocznie prawie 70 miliardów dolarów, a dodatkowo 30 miliardów wydawane jest na działania, których celem jest obniżenie masy ciała np. specjalne programy, specjalne produkty żywnościowe i różnego typu środki mające wspomagać odchudzanie (6).

\section{Tkanka tłuszczowa - rola w organizmie człowieka}

Tkanka tłuszczowa pełni w organizmie wiele ważnych funkcji. Przede wszystkim stanowi ona magazyn kwasów tłuszczowych będących głównym substratem energetycznym, czyli związkiem, z którego komórki różnych tkanek wytwarzają energię niezbędną dla przebiegu procesów metabolicznych. W komórkach tkanki tłuszczowej (adipocytach) kwasy tłuszczowe gromadzone są w postaci związków zwanych triglicerydami. Triglicerydy syntetyzowane są $\mathrm{w}$ tych komórkach z dostarczanych z pożywieniem kwasów tłuszczowych i glukozy. Magazynowanie energii w postaci odpowiednich związków chemicznych jest mechanizmem zabezpieczającym prawidłowe funkcjonowanie organizmu. W przypadku braku dopływu energii z zewnątrz (tzn. z pożywieniem) a także w przypadku zwiększonego jej wydatkowania (np. w trakcie długotrwałej pracy fizycznej) organizm wykorzystuje zgromadzone zapasy substratów energetycznych. Wówczas z ko- 
mórek tkanki tłuszczowej uwalniane są kwasy tłuszczowe, które transportowane są do komórek różnych tkanek i tam wykorzystywane.

Podskórna tkanka tłuszczowa pełni rolę izolacji termicznej: chroni organizm przed utratą ciepła, pomaga w utrzymaniu stałej temperatury ciała.

Tkanka tłuszczowa jest miejscem, gdzie syntetyzowanych jest wiele substancji zwanych adipokinami, do których należą leptyna, adiponektyna, rezystyna, a także białko stymulujące acylację, inhibitor-1 tkankowego aktywatora plazminogenu, angiotensynogen oraz wiele cytokin. Substancje te wpływają na przebieg różnych reakcji i procesów zachodzących w organizmie m.in. metabolizm lipidów i glukozy, aktywność fibrynolityczną osocza, odpowiedź immunologiczną, dojrzewanie płciowe.

Szerokie działanie związków syntetyzowanych w komórkach tkanki tłuszczowej sprawia, że ilość tkanki tłuszczowej jest ważnym czynnikiem zapewniającym prawidłowy rozwój i działanie organizmu. Zarówno niedobór jak i nadmiar tkanki tłuszczowej stwarzają sytuacje, w których może dochodzić do zaburzeń różnych procesów, co z kolei może sprzyjać powstawaniu różnych chorób (7-24).

\section{Tkanka tłuszczowa a bilans energetyczny organizmu}

Poziom tkanki tłuszczowej w organizmie jest obrazem jego bilansu energetycznego będącego obrazem relacji miedzy ilością energii dostarczanej a ilością energii wydatkowanej przez organizm (20). Jeśli dowóz energii przewyższa jej zużycie, to nadmiar dostarczonej energii jest odkładany w postaci odpowiednich związków głównie w tkance tłuszczowej, co wiąże się ze wzrostem ilości tej tkanki a objawia się wzrostem masy ciała. Mówimy wówczas o dodatnim bilansie energetycznym organizmu. Jeśli zaś wydatek energetyczny jest wyższy od dowozu energii, to mamy do czynienia z ujemnym bilansem energetycznym i organizm musi wykorzystywać zapasy substratów energetycznych w celu pokrycia swojego zapotrzebowania na energię. Utrzymanie masy ciała na stałym poziomie wymaga, aby dobowy bilans energetyczny był równy zeru, a więc ilość energii dostarczanej była równa ilości energii wydatkowanej przez organizm. Wydatek energetyczny organizmu to energia zużywana w procesach metabolicznych, termogenezie oraz podczas wykonywania aktywności (pracy) fizycznej. Główny wydatek energetyczny organizmu związany jest $\mathrm{z}$ aktywnością fizyczną. Ludzie wykonujący ciężkie prace fizyczne, ludzie uprawiający sport mają znacznie większy wydatek energetyczny niż osoby o siedzącym trybie życia.

Rozwój technologiczny i cywilizacyjny przejawiający się w automatyzacji produkcji, powszechnym stosowaniu urządzeń ułatwiających codzienne czynności np. prace domowe jak pranie, sprzątanie; a także rozwoju motoryzacji, którego efektem jest powszechne korzystanie $\mathrm{z}$ samochodów, sprawił, iż istotnie zmalał wydatek energetyczny związany z pracą zawodową oraz inną działalności 
codzienną. Zmiany dotyczą również sposobu spędzania czasu wolnego. Dla dużej części społeczeństwa jest to czas spędzany przed telewizorem lub komputerem. Średnie dzienne zapotrzebowanie dorosłego człowieka o niskiej aktywności fizycznej oscyluje ok. $2000 \mathrm{kcal} /$ dzień i zależy od płci, wieku, wielkości organizmu, stanu fizjologicznego. Dorosła osoba o masie ciała równej $70 \mathrm{~kg}$ zużywa podczas snu ok. $65 \mathrm{kcal} /$ godz, a podczas leżenia i oglądania telewizji ok. $80 \mathrm{kcal} /$ godz. Podczas 1-godzinnego spaceru traci ok. $200 \mathrm{kcal}$ a szybkiego marszu $(6 \mathrm{~km} /$ godz) ok. $350 \mathrm{kcal} .450 \mathrm{kcal}$ traci grając 1 godzinę w tenisa, a ok. $600 \mathrm{kcal}$ jeśli przez godzinę jeździ szybko na rowerze, biega lub wykonuje inne bardzo forsowne ćwiczenia fizyczne.

Określając poziom dostarczanej energii należy pamiętać, iż najwyższą wartość kaloryczną mają produkty/potrawy wysokotłuszczowe oraz słodycze, a najniższą warzywa i owoce. Komponując swoje posiłki trzeba brać pod uwagę wartość odżywczą oraz energetyczną poszczególnych produktów. Informacje te znajdujemy na opakowaniach licznych produktów. Zawarte są one również w różnego typu publikacjach. Najlepszym źródłem tych danych są tabele wartości odżywczej żywności (25). W oparciu o te dane poniżej przedstawiono wartość energetyczną kilkunastu wybranych produktów.

\begin{tabular}{|l|c|c|}
\hline \multicolumn{2}{|c|}{ Wartość energetyczna wybranych produktów spożywczych } \\
\hline \multicolumn{1}{|c|}{ Produkt } & Ilość & Wartość energetyczna- kcal \\
\hline Chleb biały & 1 kromka $-30 \mathrm{~g}$ & 75 \\
Chleb żytni razowy & 1 kromka $-30 \mathrm{~g}$ & 72 \\
Kajzerka & 1 sztuka $-50 \mathrm{~g}$ & 120 \\
Mleko 3.5\% tłuszczu & 1 szklanka $-250 \mathrm{ml}$ & 153 \\
Mleko 2\% tłuszczu & 1 szklanka $-250 \mathrm{ml}$ & 118 \\
Ser twarogowy chudy & $100 \mathrm{~g}$ & 104 \\
Ser ementaler tłusty & $100 \mathrm{~g}$ & 330 \\
Wołowina surowa chuda & $100 \mathrm{~g}$ & 120 \\
Kurczak bez kości & $100 \mathrm{~g}$ & 120 \\
Dorsz - filet & $100 \mathrm{~g}$ & 64 \\
Węgorz & $100 \mathrm{~g}$ & 198 \\
Makrela wędzona & $100 \mathrm{~g}$ & 155 \\
Boczek wędzony & $100 \mathrm{~g}$ & 475 \\
Big Mac & 1 sztuka & 540 \\
Ziemniaki & $100 \mathrm{~g}$ & 59 \\
Frytki & 1 porcja $-190 \mathrm{~g}$ & 560 \\
Chipsy bekonowe & $100 \mathrm{~g}$ & 537 \\
Buraki & $100 \mathrm{~g}$ & 34 \\
Marchew & $100 \mathrm{~g}$ & 25 \\
Pomidory & $100 \mathrm{~g}$ & 28 \\
Ogórek & $100 \mathrm{~g}$ & 13 \\
Truskawki & $100 \mathrm{~g}$ & 29 \\
Jabłka & $100 \mathrm{~g}$ & 42 \\
Cukier & $100 \mathrm{~g}$ & 40 \\
Cukierki „Ptasie mleczko” & $100 \mathrm{~g}$ & 473 \\
Cukierki „Michałki” & 1 sztuka - $100 \mathrm{~g}$ & 549 \\
Czekolada mleczna & 1 sztuka - 75 g & 549 \\
Baton Mars & & 339 \\
\hline
\end{tabular}




\section{Wskaźnik masy ciała a nadwaga i otyłość}

Łatwość dostarczania energii związana z dużą dostępnością żywności i niski wydatek energetyczny związany z małą aktywnością fizyczną sprzyjają powstawaniu dodatniego bilansu energetycznego, a więc gromadzeniu zapasów substratów energetycznych w tkance tłuszczowej.

Aktualnie dysponujemy różnymi metodami pozwalającymi ocenić zawartość tkanki tłuszczowej w organizmie (15). W praktyce dokonuje się tej oceny przede wszystkim w oparciu o ocenę wskaźnika masy ciała (BMI) będącego stosunkiem masy ciała (wyrażonej w kilogramach) do kwadratu wzrostu (wyrażonego w metrach kwadratowych): BMI = masa ciała $[\mathrm{kg}] /$ wzrost $^{2}\left[\mathrm{~m}^{2}\right]$

Zakres prawidłowych wartości wskaźnika BMI ustalono na podstawie obserwacji zależności między masą ciała a częstością rozwoju określonych chorób, częstością zgonów spowodowanych różnymi chorobami, długością życia. W oparciu o te obserwacje określono najkorzystniejsze wartość BMI, a tym samym najkorzystniejszy zakres masy ciała dla kobiet i mężczyzn. Za prawidłowe przyjęto wartości BMI w granicach 18.5-24.9. Wartości BMI poniżej 18.5 świadczą o niedoborze masy ciała. Wartości między 25-29.9 uznaje się za nadwagę a wartości powyżej 30 za otyłość $(2-5,15,23)$. Wskaźnik BMI jest powszechnie używany do oceny prawidłowości/nieprawidłowości masy ciała, rozpoznawania nadwagi i otyłości. Są oczywiście przypadki, w których nie należy się nim posługiwać. Nie korzysta się z niego m.in. w badania kobiet ciężarnych, pacjentów dializowanych czy osób aktywnie uprawiających sport i intensywnie zwiększających masę mięśniową.

W Polsce wg. wyników badań epidemiologicznych NATPOL III PLUS (26) w 2002 roku nadwaga występowała u prawie 35\% dorosłych Polaków a otyłość u prawie 20\%. Wyniki badan POL-MONICA przeprowadzonych w roku 2001 w Warszawie, w grupie mężczyzn i kobiet w wieku 35-64 lata, wykazały występowanie nadwagi u 34.4\% kobiet i 44.2\% mężczyzn, a otyłości u 27.1\% kobiet i 30.8\% mężczyzn (4). Zaobserwowano ponadto, że wśród warszawskich mężczyzn częstość otyłości w roku 2001 była ponad 11\% wyższa niż w roku 1988 (30.8\% vs 19.7\%), (2-4).

Stwierdzono, iż u osób z BMI > 26 (a więc u osób z nadwagą i otyłością) $\mathrm{w}$ porównaniu $\mathrm{z}$ osobami z BMI $<21$, ryzyko rozwoju niedokrwiennej choroby serca jest prawie 2-razy wyższe, a ryzyko wystąpienia cukrzycy typu II wzrasta 4-krotnie w grupie mężczyzn i 8-krotnie w grupie kobiet (15-19). Stopień ryzyka wystąpienia zaburzeń powstających na tle otyłości rośnie wraz ze wzrostem stopnia nadwagi i otyłości.

\section{Kluczowa rola czynników środowiskowych w rozwoju otyłości}

Żywność będąca źródłem energii i substancji odżywczych należy do głównych czynników środowiskowych oddziaływujących na organizm człowieka. 
Spożywanie żywności to jedna z podstawowych funkcji fizjologicznych organizmu. Nasz genom, nasz organizm i jego funkcje kształtowały się wiele milionów lat temu, kiedy dostęp do żywności był ograniczony i warunkiem przetrwania oraz rozwoju organizmu było kształtowanie mechanizmów sprzyjających akumulacji energii. Ośrodki kierujące procesem dostarczania i wydatkowania energii znajdują się w mózgu (20). Odbierają one sygnały wysyłane przez różne tkanki i narządy np. układ pokarmowy, endokrynny, tkankę tłuszczową. Sygnały te informują zarówno o potrzebach organizmu jak i środowiskowych możliwościach ich zaspokajania. W oparciu o te informacje mózg wysyła sygnały uruchamiające dowóz lub wydatkowanie energii.

Jesteśmy wrażliwi na bardzo wiele bodźców stymulujących dostarczanie energii. Są to nie tylko bodźce płynące z układu pokarmowego, ale także bodźce wzrokowe, węchowe. Chęć spożywania pokarmu pojawia się m.in. gdy widzimy określone produkty lub czujemy ich zapach. Mamy zdolność spożywania żywności, kiedy nie odczuwamy głodu. Nasz system dostarczania energii i gromadzenia zapasów jest dobrze rozwinięty. Można powiedzieć, iż zawdzięczamy mu nasze istnienie. Dzięki niemu człowiek mógł przetrwać okresy niedoboru czy braku pożywienia. Obecnie, w okresie szerokiego dostępu do żywności, w tym produktów o wysokiej wartości energetycznej, system ten ułatwia nam nadmierne dostarczanie pokarmu, a więc nadmierny dowóz energii znacznie przekraczający potrzeby organizmu.

Główną przyczyną otyłości jest lekceważenie zasad racjonalnego żywienia i niska aktywność fizyczna (27). Ludzie z reguły nie poprzestają na spożywaniu zasadniczych posiłków. Wielokrotnie w ciągu dnia sięgają po przekąski. Zazwyczaj są to wysokokaloryczne produkty takie jak różnego typu słodycze, słodkie napoje gazowane, chipsy, frytki (28). Ponadto coraz częściej posiłkami zasadniczymi są produkty typu „fast food” o wysokiej kaloryczności i wysokiej zawartości tłuszczu o niekorzystnym dla zdrowia profilu kwasów tłuszczowych. Taki sposób żywienia charakteryzuje się nie tylko wysokim dowozem energii, lecz także niskim poziomem spożycia wielu składników odżywczych np. składników mineralnych, witamin, flawonoidów, wielonienasyconych kwasów tłuszczowych. Nieprawidłowa wartość odżywcza posiłków, nadmierne spożycie tłuszczów bogatych w nasycone kwasy tłuszczowe oraz węglowodanów prostych, niskie spożycie węglowodanów złożonych a zwłaszcza błonnika pokarmowego, nieprawidłowości w dowozie składników mineralnych i witamin sprzyjają powstawaniu licznych zaburzeń metabolicznych (29-31). Ponadto ludzie nie przywiązują wagi do poziomu aktywności fizycznej. $\mathrm{Z}$ reguły nie zdają sobie sprawy, że codzienne czynności wiążą się z niskim wydatkiem energetycznym. Powszechnie obserwowane obniżenie aktywności fizycznej oraz nieprawidłowy sposób żywienia dotyczą zarówno osób dorosłych jak i dzieci. Dlatego nadwaga i otyłość, chociaż są kluczowym problemem osób dorosłych, to jednak coraz częściej występują u dzieci i młodzieży. 
Rozwój otyłości zależy nie tylko od czynników środowiskowych, ale także od czynników genetycznych. Dlatego jednym z kluczowych elementów badań naukowych jest określenie czynników genetycznych zwiększających podatność do akumulacji tkanki tłuszczowej. Poznanie tych regulacji będzie pomocne w opracowaniu skutecznych programów przeciwdziałania i leczenia otyłości.

Dotychczasowe badania jednoznacznie pokazują, że czynniki genetyczne są czynnikami sprzyjającymi a nie czynnikami determinującymi rozwój otyłości, tzn. określają, czy łatwo możemy stać się otyli, nie decydują natomiast o tym, czy będziemy otyli. Przypadki silnego genetycznego uwarunkowania rozwoju otyłości występują bardzo rzadko. Znaleziono zaledwie kilka takich przypadków na świecie. Dlatego też podstawą walki z otyłością jest edukacja w zakresie zasad prawidłowego żywienia i zdrowego stylu życia zapewniającego odpowiedni poziom aktywności fizycznej.

\section{Przeciwdziałanie powstawaniu nadwagi i otyłości}

Walka z nadwagą i otyłością, chociaż opiera się na jasnych i sprecyzowanych zasadach, jest sprawą niezwykle trudną (32). Dotyczy bowiem regulacji podstawowych zachowań dotyczących komponowania i spożywania posiłków, sposobów spędzania wolnego czasu i wielu innych elementów stylu życia. Nieodpowiednie zachowania, jak np. nadmierne spożywanie wysokokalorycznej żywności, spędzanie czasu wolnego przed telewizorem, są efektem złych nawyków, braku wiedzy, często także reakcją na stres, przejawem kłopotów emocjonalnych. Jeśli spotyka nas coś nieprzyjemnego, to często poprawiamy sobie humor spożywaniem słodyczy lub innych ulubionych produktów.

Podjęcie działań mających na celu obniżenie masy ciała musi wiązać się ze zmianą wielu elementów stylu życia. Efektywność tych działań zależy od uświadomienia sobie przez pacjenta konieczności ich przeprowadzenia oraz od odpowiedniego ich zaprogramowania. Dlatego należy je podejmować po konsultacji ze specjalistami, przede wszystkim lekarzem i dietetykiem, który w oparciu o wskazania lekarza określi odpowiednie zasady zmiany diety. Samodzielnie przeprowadzane, długotrwałe restrykcje dietetyczne mogą stać się przyczyną niepożądanych zaburzeń $w$ funkcjonowaniu organizmu.

Bardzo często, zwłaszcza u osób z kłopotami emocjonalnymi, niezmiernie pomocne są działania psychologa. Ponieważ najlepsze rezultaty odchudzania uzyskuje się łącząc niskokaloryczną dietę z ćwiczeniami fizycznymi, dlatego w prowadzeniu programów odchudzających ważną rolę odgrywają fizjoterapeuci i specjaliści z zakresu kultury fizycznej dostosowujący plan i zakres ćwiczeń do możliwości osób odchudzających się. W profilaktyce nadwagi i otyłości niezwykle ważną rolę odgrywa wyrobienie nawyku do regularnego, aktywnego spędzania czasu wolnego, udziału w zajęciach sportowych itp. 
Wysoka częstość nadwagi i otyłości oraz duża liczba osób próbujących obniżyć swoją masę ciała i poszukujących łatwych oraz szybkich sposobów uzyskania tego efektu sprawia, że rynek pełen jest specjalnych produktów reklamowanych jako redukujące masę ciała. Przeprowadzone ostatnio analizy badań dotyczących skuteczności stosowania tych preparatów nie udokumentowały ich istotnego wpływu na uzyskanie spadku masy ciała (33). W oparciu o wyniki tych analiz można stwierdzić, że nie ma podstaw do rekomendowania stosowania tych preparatów na szeroką skalę. W określonych, jednostkowych przypadkach mogą one ułatwić wprowadzanie odpowiedniego programu redukcji masy ciała. Nie zastąpią jednak konieczności dokonania istotnych zmian w sposobie żywienia i stylu życia.

Zapobieganie otyłości to problem niezwykle ważny zarówno z punktu widzenia zdrowia jednostki jak i zdrowia zbiorowości - zdrowia publicznego. W 1999 roku przyjęto, w czasie obrad IX Europejskiego Kongresu Naukowego nt. Otyłości, tzw. deklarację Mediolańską, która wzywa rządy i organizacje ochrony zdrowia w Europie do opracowania i wdrożenia narodowych strategii przeciwdziałania otyłości. Światowa Organizacja Zdrowia przygotowała rekomendacje w zakresie zapobiegania i leczenia otyłości, a podpisany w maju 2004 roku w Genewie na 57 Światowym Zgromadzeniu WHO dokument „Globalna strategia dotycząca diety, aktywności fizycznej i zdrowia” wzywa wszystkie kraje świata do istotnego wzmożenia działań w kierunku racjonalizacji żywienia i zwiększenia aktywności fizycznej w celu poprawy stanu zdrowia ludności.

\section{Piśmiennictwo}

1. World Health Organization. Executive Summary. June 3-5, 1997, Geneva, Switzerland.http:/www.who.int/nut/documents/obesity_executive_summary.pdf.

2. Rywik S. i wsp. Program Pol-MONICA Warszawa. Kompleksowa ocena stanu zdrowia ludności Warszawy i jego zmian w latach 1984-1990. Instytut Kardiologii, Warszawa 1993.

3. Rrwik S. i wsp. Program Pol-MONICA Warszawa. Kompleksowa ocena stanu zdrowia ludności Warszawy w roku 1993 i jrgo zmian w latach 1984-1993. Instytut Kardiologii, Warszawa 1995.

4. Rywik S. i wsp. Program Pol-MONICA BIS Warszawa. Stan zdrowia ludności Warszawy w roku 2001. Instytut Kardiologii, Warszawa 2002.

5. Diet, nutrition and prevention of chronic disease. Report of a joint $\mathrm{WHO} /$ FAO experts consultation. WHO, Geneva 2003.

6. Long term pharmacotherapy in the management of obesity. National Task Force on the Prevention and Treatment of Obesity. JAMA 1996, 276:1907-15 . 
7. National Task Force on the Prevention and Treatment of Obesity. Overweight, obesity, and health risk. Arch Intern Med 2000, 160: 898-904.

8. Jung RT. Obesity as a disease. Br Med Bull 1997, 53: 307-21.

9. Jousilahti $P$ et al. Body weight, cardiovascular risk factors and cardiovascular mortality: 15 year follow-up of middle aged men and women on eastern Finland. Circulation 1996, 93: 1372-79

10. National Task Force on the Prevention and Treatment of Obesity. Dieting and the development of eating disorders in overweight and obese adults. Arch Int Med 2000. 160: 2581-9

11. Buselto L. Visceral obesity and the metabolic syndrome: effects of weight loss. Nutr Metab Cardiovasc Dis 2001, 11: 195-204

12. Key TJ et al. The effect of diet on risk of cancer. Lancet 2002, 360: 861-8

13. Kenchaiah $S$ et al. Obesity and the risk of heart failure. N Engl J Med 2002, 347: 305-13

14. Rocchini AP. Obesity and blood pressure regulation. W Bray AG, Bouchard C, James WP: "Handbook of obesity"; Marcel Dekker, New Yourk 2003.

15. WiLlet W et al. Guidelines for healthy weight. N Engl J Med 1999, 341: 427-34 .

16. RIMm EB et al. Body size and fat distribution as predictors of coronary heart disease among middle aged and older US men. Am J Epidemiol 1995, 141;1117-27

17. Chan JM et al. Obesity, fat distribution and weight gain as factors for clinical diabetws in men. Diabetes Care 1994, 17: 961-9.

18. WILLET WC et al. Weight, weight change, and coronary heart disease in women: risk within the normal weight range. JAMA 1995, 273: 461-5.

19. Colditz GA et al. Weight gain as a risk factor for clinical diabetes mellitus in women. Arch Int Med 1995, 122:481-6.

20. Schwartz MW et al. Model for the regulation of energy balance and adiposity by the central nervous system. Am J Clin Nutr 1999, 69: 584-96.

21. Yuji M et al. Adiponectin and Metabolic Syndrome. Arterioscler Thromb Vasc Biol 2004, 24:29-33.

22. Mazurek T et al. Human epicardial adipose tissue is a source of inflammatory mediators. Circulation 2003, 108:2460-66.

23. ECKel RH, Krauss RM for the AHA Nutrition Committee: American Heart Association call to action: obesity a major risk factor for coronary heart disease. Circulation 1998, 97: 2099-2100 .

24. Sodar $S$ et al. Leptin - a novel link between obesity, diabetes, cardiovascular risk and ventricular hypertrophy. Circulation 2003, 108:644-6.

25. Kunachowicz H., Nadolna I., Przygoda B., Iwanow K., Tabele wartości odżywczej produktów spożywczych. Wyd.- IŻŻ, Warszawa 1998.

26. Wyrzykowski B., Zdrojewski T., 2003. Program NATPOL PLUS 2002; www.natpol.pl 
27. Jeguier E., pathways to obesity. Int.J Obesity 2002, Suppl.2:12-17.

28. SChultze MB et al. Sugar-sweetened beverages, weight gain, and incidence of type 2 diabetes in young and middle aged women. JAMA 2004, 292:978$-79$.

29. Nowicka G., Żywienie a prewencja chorób układu krążenia. Studia Ecologie et Bioethicae 2003, 1:103-114.

30. Haffner S., Taegtmeyer H., Epidemic obesity and the metabolic syndrome. Circulation 2003, 108:1541:5.

31. Falber J., Golay A., Pathways from obesity to diabetes. Int J Obesity 2002, 26, Suppl 2: 39-45.

32. Food and Health for Europe: A new basis for action. WHO 2004.

33. Pittler MH., ERnst E., Dietary supplements for body-weight reduction: a systemic review. Am J Clin Nutr 2004, 79:529-36.

\title{
Obesity - a great public health problem
}

\begin{abstract}
Obesity affecting more than $30 \%$ of adult population has been recognized as a major public health problem. Overweight and obesity generally are caused by unhealthy eating patterns and a lack of physical activity. Managing of obesity and overweight is of paramount importance because of well established relations between excess body mass and different diseases such as coronary heart disease, type 2 diabetes, hypertension, and some types of cancer. Guidelines for reducing the risk of obesity and obesity-related disorders by dietary changes, increased physical activity and other lifestyle practices have been prepared by healthcare professionalists. WHO prepared the draft of global strategy on diet, physical activity and health, which should be adopted and developed at regional and national levels. Appropriate public knowledge on relationship between diet, physical activity, obesity and health provides a base for prevention of obesity and obesity related disorders.
\end{abstract}

